\title{
Proses Belajar Mengajar Selama Pandemi COVID-19 Pada Tingkat Sekolah Dasar Di Kalimantan Barat
}

\author{
Suparjan $^{1}$, Mariyadi $^{2}$ \\ FKIP-PGSD Universitas Tanjungpura Pontianak ${ }^{1}$, FKIP-Pendidikan Bahasa \\ Indonesia Universitas Tanjungpura Pontianak ${ }^{2}$ \\ suparjan@untan.ac.id ${ }^{1}$
}

\begin{abstract}
Abstrak
Penelitian ini bertujuan untuk menginvestigasi pelaksanaan kegiatan belajar dan mengajar tingkat sekolah dasar di Kalimantan Barat pada masa pandemi COVID-19. Penelitian ini menggunakan metode deskriptif kualitatif dengan teknik pengumpulan data berupa wawancara semi terstruktur terhadap guru-guru di sekolah dasar. Hasil penelitian menunjukkan bahwa terdapat dua jenis pola pembelajaran yang dilakukan oleh guru-guru di masa pandemi COVID-19 yaitu pembelajaran daring dan luring. Pertama kegiatan pembelajaran daring yang umumnya dilakukan oleh guru melalui aplikasi media sosial berupa WhatsApp. Kegiatan belajar dan mengajar dilakukan dengan cara mengirim teks, video, rekaman suara, dan power point, kepada siswa. Kedua kegiatan pembelajaran luring yang dilakukan oleh guru dengan memberikan tugas mingguan, pembelajaran secara berkelompok, dan pembelajaran dengan les. Hambatan-hambatan yang dihadapi oleh guru selama proses kegiatan belajar dan mengajar di masa pandemi COVID 19 di antaranya adalah kurangnya ketersediaan perangkat pembelajaran daring, sumber daya manuasia (SDM) yang kurang mumpuni, dan sikap negatif baik itu berasal dari guru, siswa, maupun orang tua.
\end{abstract}

Kata Kunci: daring, luring, kegiatan belajar dan mengajar, pandemi. 


\section{PENDAHULUAN}

Corona Virus Disease (COVID-19) merupakan penyakit yang disebabkan oleh virus sebagai turunan dari virus corona. Virus ini merupakan keluarga virus Severe Acite Respiratory Syndrom (SARS) dan jenis virus flu biasa (UNICEF, WHO, IFRC, 2020). Kasus pertama COVID-19 berasal dari Provinsi Hubei, China sejak Desember 2019 (BBC, 2020). Di Indonesia kasus pertama diumumkan pada tanggal 2 Maret 2020 (Kompas, 2020). Kasus tersebut pun mulai mengalami peningkatan. Pembatasan Berskala Besar (PSBB) pun dilaksanakan oleh pemerintah Republik Indonesia yang pertama kali diterapkan di Jakarta pada 10 April 2020 yang selanjutnya diikuti di lingkup provinsi, kabupaten, atau kota lain yang mengalami peningkatan kasus yang signifikan (Muhyidin, 2020). Dengan diterapkannya PSBB, hampir semua pelayanan pemerintahan dan non-pemerintahan untuk sementara dihentikan. Tidak terkecuali pelayanan pendidikan yang harus dilaksanakan ke dalam Bentuk Pembelajaran Dari Rumah (BDR) atau biasa dikenal dengan Pembelajaran Jarak Jauh (PJJ) (Kemendikbud, 2020).

Wabah COVID-19 memaksa seluruh elemen yang terlibat dalam pendidikan untuk beradaptasi terhadap perubahan cara dan bentuk pembelajaran. Elemen tersebut termasuklah guru dan murid yang harus beradaptasi terhadap budaya belajar dengan memanfaatkan teknologi secara maksimal (Purwanto, dkk., 2020). Begitu juga orang tua murid yang secara tiba-tiba harus menjadi fasilitator belajar siswa dan harus mengeluarkan dana lebih terutama dalam menjamin ketersediaan kuota internet agar PJJ dapat berjalan dengan baik (Dina, 2020).

Pembelajaran merupakan usaha guru untuk menciptakan kondisi atau mengatur lingkungan sehingga terjadi interaksi proses belajar (Abdul Ghofir, dkk., dalam Hanafi dkk, 2019, hal.59). Guru dituntut untuk menguasai teknologi sebagai tuntutan Era Revolusi Industri 4.0 (Widaningsih, 2019, hal.25). Manfaatnya adalah pada masa darurat COVID-19 yang mengharuskan guru untuk mampu mengatur pembelajaran secara baik dengan menggunakan teknologi yang telah ada.

Pembelajaran yang menekankan pada pembelajaran tanpa tatap muka tersebut terdiri atas dua pendekatan yakni secara daring dan luring (Gusti dkk, 2020, hal.81). Pembelajaran secara daring merupakan pembelajaran yang mengondisikan peserta didik dan gurunya tidak pada tempat yang sama sehingga memerlukan bantuan 
jaringan internet Meidawati, dkk (dalam Pohan, 2020, hal.2-3). Pembelajaran daring tersebut baik berupa sinkron yang berarti guru dan siswa melakukan proses pembelajaran dalam waktu yang sama namun pada tempat yang berbeda seperti penggunaan media video conference ataupun dengan asinkron yang berarti pembelajaran dengan bantuan internet namun guru dan siswa tidak pada waktu yang sama seperti penggunaan hasil rekaman video, google formulir dan lain sebagainya Yuliani, ddk (2020, hal.87-88). Sedangkan pembelajaran luring adalah pembelajaran tanpa tatap muka yang memerlukan jaringan internet seperti menggunakan media televisi, modul, lembar kerja siswa (LKS) dan lain sebagainya (Yuliani, dkk. 2020, hal.87).

Pembelajaran selama masa pandemi COVID-19 melalui pembelajaran daring dan luring tanpa tatap muka memberikan solusi yang efektif untuk mengaktifkan kelas meski aktivitas belajar mengajar di sekolah dihentikan (Herliandry, dkk., 2020). Pemanfaatan teknologi informasi dalam pembelajaran memudahkan guru dan siswa dalam pemilihan media pembelajaran yang dapat digunakan di mana saja (Amrihani, dkk., 2020, hal.245). Waktu yang digunakan dalam PJJ pun sangat efektif. Siswa tidak perlu datang ke sekolah sehingga bisa menghemat waktu dan tenaga (Zulkifli dkk., 2020, hal.342).

Selama pelaksanaan PJJ dimasifkan, terdapat kendala yang dihadapi oleh guru dan siswa. Proses pembimbingan belajar tidaklah seefektif pembelajaran tatap muka. Anggrawan (dalam Sudarsana, dkk., 2020, hal.101) mengungkapkan bahwa pembelajaran daring mengharuskan siswa untuk belajar mandiri. Ketidakhadiran guru dalam proses pembelajaran di rumah mengakibatkan kurangnya motivasi belajar siswa sehingga pembentukan nilai dalam proses belajar mengajar berjalan dengan lamban. Belum lagi hambatan tentang ketersedian kuota, banyaknya tugas, penguasaan teknologi, ketidakstabilan jaringan, dan lain sebagainya (Jamaludin, dkk., 2020).

Tingkat keefektifan dalam pelaksanaan PJJ juga dinilai kurang. Fauzi dan Khusuma (2020) melalui penelitiannya tentang perspektif guru Sekolah Dasar (SD) pada 45 guru di Banten dan Jawab Barat, mengungkapkan bahwa hampir 80\% guru merasa tidak puas dengan sistem pembelajaran daring di SD. Hal tersebut dikarenakan tidak semua siswa pernah dan mengetahui media yang digunakan pada 
pembelajaran daring, kurangnya akses jaringan yang sangat berpengaruh terhadap kelangsungan proses belajar-mengajar daring, dan sulitnya dalam melakukan perencanaan, pelaksanaan, dan evaluasi dan kesulitan dalam rangka melakukan kerjasama dengan orang tua. Menurut Naziah, dkk., (2020) faktor lain yang juga menghambat PJJ selama pademi COVID-19 di SD adalah tidak tersedianya alat peraga dalam belajar dan kondisi ekonomi orang tua siswa, budaya, atau anggapan dari masyarakat bahwa pembelajaran daring hanya memberikan beban sehingga siswa tidak memiliki motivasi tinggi dalam pembelajaran yang dilaksanakan.

Tersedianya banyak pilihan teknologi informasi yang dapat digunakan dalam PJJ memungkinkan guru untuk kreatif. Guru, siswa, dan orang tua secara bebas menentukan media pembelajaran dengan memperhatikan beberapa prinsip. Prinsip yang paling mendasar dalam pemilihan media pembelajaran di masa COVID-19 adalah bahwa aktivitas penugasan selama belajar harus mempertimbangkan akses terhadap fasilitas PJJ. Media dan sumber pembelajaran dengan pendekatan daring yang dapat digunakan diantaranya, Rumah Belajar oleh Pusdatin Kemendikbud, TV Edukasi Kemendikbud, Pembelajaran Digital oleh Pusdatin dan SEAMOLEC Kemendikbud dan lain sebagainya. Media dan sumber pembelajaran dengan pendekatan luring yang dapat digunakan diantaranya program televisi khusus program belajar dari rumah, radio, modul belajar mandiri dan lembar kerja, bahan ajar cetak, dan alat peraga dan media belajar dari benda lingkungan sekitar (Kemendikbud, 2020).

Rasmitadila, dkk. (2020) melalui risetnya berhasil mengungkap media apa saja yang digunakan oleh guru dalam pelaksanaan pembelajaran di masa pademi COVID-19 di Indonesia. Beberapa guru menggunakan video yang telah tersedia di kanal YouTube sebagai media pembelajaran. Selain itu terdapat juga pemanfaatan media sosial seperti WhatsApp, Google Forms, Worksheet, dan Zoom sebagai media pembelajaran. Guru memanfaatkan WhatsApp, Google Forms, dan LKS untuk mengirim tugas kepada orang tua siswa yang selanjutnya dberikan kepada peserta didik. Sedangkan metode yang paling sering digunakan adalah metode Question \& Answer (Q\&A) dan metode diskusi dengan bantuan media yang telah disebutkan sebelumnya. 
Dillon dan Gunwarden (dalam Pangondian, 2019) menjelaskan bahwa terdapat tiga faktor yang menjadi penentu berhasilnya pembelajaran secara daring. Pertama, teknologi yang secara khusus pengaturan jaringan. Kedua, karakteristik pengajar yang menerapkan instruksional yang mampu memberikan umpan positif kepada peserta didik. Ketiga, karakteristik siswa yang menurut Leidner (dalam Andrianto, 2019) siswa yang cerdas, disiplin, dan percaya diri mampu melakukan pembelajaran dengan metode daring.

Selain faktor teknologi dan karakteristik pengajar, keberhasilan penerapan PJJ juga dipengaruhi oleh motivasi belajar peserta didik. Keberhasilan tersebut dapat ditempuh dengan menjalin kerjasama antara guru, siswa, dan orang tua yang menjadi pembimbing anak saat pembelajaran di rumah dilaksanakan sehingga motivasi belajar anak menjadi meningkat (Dewi, 2020). Situasi lingkungan sebagai faktor eksternal sangat sangat berpengaruh terhadap tingginya tingkat motivasi siswa dalam belajar (Cahyani, dkk., 2020).

Motivasi belajar siswa dalam PJJ dapat ditingkatkan melalui beberapa cara yang salah satunya dapat ditempuh dengn penggunaan metode publikasi hasil belajar siswa seperti yang dilaporkan Fadlilah (2020) bahwa metode publikasi hasil belajar siswa pada Kelompok Bermain (KB) TK Al-Huda Kota Malang mampu meningkatkan motivasi belajar. Selanjutnya motivasi belajar siswa dapat juga ditempuh melalui strategi komunikasi persuasif baik secara kelompok maupun secara pribadi seperti yang dilakukan oleh Suryaningsih (2020) terhadap pembelajaran animasi 2D pada siswa SMK Negeri 2 Sewon Bantul. Penggunaan model pembelajaran juga Project Based Learning juga mampu meningkatkan motivasi siswa dalam PJJ seperti yang dilakukan Handayani (2020) pada pembelajaran IPA bagi siswa SMPN 4 Gunungsari.

Kalimantan Barat telah melaksanakan program BDR sejak penghentian sementara kegiatan belajar mengajar di sekolah mulai tanggal 16 Maret 2020 yang diintruksikan oleh Gubernur Kalimantan Barat, Sutarmidji (Suara Kalbar, 2020). Beberapa sekolah termasuklah SD di Kalimantan Barat memanfaatkan berbagai macam cara dan media baik itu secara daring ataupun luring. Herman (Kantor Berita Antara Kalbar, 2020), Kepala Dinas Pendidikan Provinsi Kalimantan Barat, mengatakan bahwa proses pembelajaran daring di masa pandemi tidak berjalan 
optimal. Hal tersebut dikarenakan tidak meratanya akses internet di sekolah maupun di area tempat tinggal siswa. Beberpa guru bahkan menggunakan memanfaatkan SMS untuk mengirim tugas kepada siswa. Berdasarkan beberapa kasus yang telah disebutkan sebelumnya, penelitian ini dinilai sangat penting untuk dilakukan agar media beserta pola BDR di Kalimantan Barat dapat diungkap.

\section{METODE PENELITIAN}

Penelitian ini menggunakan metode deskriptif dengan bentuk penelitian kualitatif. Menurut Whitney (dalam Tarjo, 2019, hal.29) penelitian deskriptif adalah penelitian yang berusaha menemukan fakta dengan interpretasi yang tepat. Hal yang dipelajari dalam penelitian deskriptif dapat berupa permasalahan yang terjadi di masyarakat, situasi tertentu, hubungan, kegiatan, sikap, pandangan, serta proses dalam sebuah fenomena di lapangan. Menurut Rukin (2019, hal.6) penelitian kualitatif adalah penelitian yang bersifat deskriptif dan biasanya menggunakan analisis dengan pendekatan induktif. Hal yang ditekankan pada penelitian kualitatif adalah makna, penalaran, dan lain sebagainya tetang kehidupan sehari-hari.

Teknik pengumpulan data dalam penelitian ini adalah dengan menggunakan teknik wawancara semi terstruktur. Menurut Suwartono (2014, hal.50) teknik wawancara semi terstruktur adalah teknik wawancara yang menempatkan pewawancara sebagai pengarah pembicaraan. Dalam teknik ini pewawancara menggembangkan pertanyaan dari topik atau isu yang ada tanpa membuat daftar pertanyaan secara lengkap. Ada pun objek yang diwawancarai dalam penelitian ini adalah guru-guru sekolah dasar yang tersebar di daerah Kalimantan Barat yang berjumlah 7 orang dengan rincian profil sebagai berikut.

Tabel 1. Profil Responden

\begin{tabular}{cccc}
\hline Inisial & Jenis Kelamin & Wilayah Kerja & Pendidikan \\
\hline R1 & Perempuan & Kapuas Hulu & S1 \\
\hline R2 & Perempuan & Kayong Utra & S1 \\
\hline R3 & Lak-Laki & Kubu Raya & S2 \\
\hline R4 & Perempuan & Kubu Raya & S1 \\
\hline R5 & Perempuan & Sambas & S1 \\
\hline R6 & Laki-Laki & Mempawah & S1 \\
\hline
\end{tabular}




\begin{tabular}{llll}
\hline R7 & Perempuan & Ketapang & S1 \\
\hline
\end{tabular}

Alat pengumpul data yang digunakan adalah berupa alat tulis, alat perekam suara, dan telepon genggam. Penelitian ini menggunakan teknik analisis data tematik dengan tujuan untuk menemukan tema dari data-data yang telah dikumpulkan oleh peneliti di lapangan (Braun \& Clarke, dalam Heriyanto, 2018). Alasan untuk memilih analisis ini bahwa teknik analisis data paling tepat untuk penelitian yang berusaha mengeksplorasi lebih dalam dan ketat terhadap temuan-temuan di lapangan adalah dengan teknik analisis data tematik (Alhojailan, dalam Purwanto, 2020).

Prosedur penelitian dalam penelitian ini terbagi atas tiga tahapan yakni, tahap pra-riset, tahap riset, dan tahap analisis data. Pada tahap prariset, peneliti mencoba mengumpulkan temuan awal tentang permasalahan yang terjadi di lapangan yang selanjutnya melakukan perencanaan penelitian dalam rangka mengumpulkan informasi tambahan baik itu informasi tentang kondisi sekolah, menentukan objek penelitian, menentukan lokasi penelitian, menentukan narasumber penelitian, mengumpulkan perlengkapan dalam penelitian seperti izin penelitian, alat tulis, alat perekam, dan alat-alat dan perlengkapan lainnya yang menunjang penelitian. Pada tahap riset, peneliti melakukan penelitian pada sekolah dasar yang telah ditentukan. Wawancara dilakukan baik itu berupa pertemuan langsung dengan guru kelas atau melakukan wawancara melalui sambungan telepon guna mendapatkan data atau informasi yang diperlukan untuk menjawab permasalahan yang dibahas dalam penelitian ini. Pada tahap analisis data, peneliti terlebih dahulu mentranskripsikan data yang semula berbentuk suara ke dalam bentuk tertulis. Data dalam bentuk tertulis diinventarisasikan dan dipilah untuk menjawab pertanyaan penelitian yang telah dibuat yakni terkait media, pola, dan kendala dalam pembelajaran selama pandemi COVID-19 sesuai keadaan yang ditemukan di lapangan. Data yang telah dipilah ditampilkan untuk selanjutnya ditarik kesimpulan sebagai kesimpulan penelitian. 


\section{HASIL DAN PEMBAHASAN}

\section{HASIL}

Tujuan dari penelitian ini adalah untuk mendapatkan informasi tentang proses kegiatan belajar mengajar di masa pandemi COVID-19. Informasi tersebut berupa hasil wawancara semi terstruktur yang dilakukan kepada beberapa responden yakni guru kelas sekolah dasar di Kalimantan Barat. Hasil wawancara tersebut lalu ditranskripsikan ke dalam bentuk tertulis dan dikutip sebagaimana yang dinyatakan oleh responden.

Seorang responden memberikan pernyataan:

“Di sekolah ini, pelaksanaannya secara luring ... dengan cara pemberian tugas ke rumah masing-masing siswa serta pengerjaannya di rumah masing-masing dengan bimbingan orang tua siswa. ... karena terbatasnya jaringan internet, ... tidak semua siswa memiliki HP,"

RI : Guru SD di Kaupaten Kapuas Hulu.

Responden lain memberikan pernyataan sebagai berikut:

"Media yang digunakan dalam pembelajaran daring adalah menggunakan media WA. Untuk dalam pola pembelajaran dan penugasan siswa, kami mengedarkan buku paket serta fotokopian yang kami serahkan kepada setiap orang tua siswa yang mengambil ke sekolah.... kami menggunakan penugasan kelompok itu dikejarkan dalam beberapa kelompok. Setiap kelompok mengambil tugasnya di sekolahan setiap satu minggu sekali,"

R2: Guru SD di Kabupaten Kayong Utara.

Responden lain memberikan pernyataan sebagai berikut:

"Media yang saya gunakan dalam pembelajaran daring yaitu dengan WA. ... Pola yang saya gunakan yaitu dengan membuat grup WA. Selanjutnya dalam proses pembelajaran didahulukan untuk absen. Setelah itu saya berikan materi berupa power point yang telah saya buat dan siswa diberikan waktu untuk bertanya. Berikutnya siswa diberikan tugas. Dan pengumpulan tugas pada pertemuan selanjutnya dalam bentuk dokumen ... agar memudahkan siswa” (R3).

R3: Guru SD di Kabupaten Kubu Raya. 
Responden lain memberikan pernyataan sebagai berikut:

"Media yang digunakan saat pembelajaran daring yaitu media WA ... kita berikan tugas siswa sesuai dengan kelompoknya masing-masing. ... karena ada anak yang tidak mempunyai HP android bisa bergabung dengan salah satu dari mereka yang memiliki HP android. Pembelajaran secara luring dilakukan dengan cara berkelompok. Alasan luring karena tidak semua siswa memiliki HP android. Tugas yang diberikan kepada siswa yaitu tugas yang diberikan secara berkelompok..

R4: Guru SD di Kabupaten Sambas.

Responden lain memberikan pernyataan sebagai berikut:

"saya menggunakan WA sebagai media belajar ... media tersebut yang paling mudah digunakan orang tua dan siswa. Jadi pertama, saya buat grup WA sesuai kelas kemudian setiap hari saya memberi materi baik berupa dokumen, rekeman suara, maupun melalui video pembelajaran. Tugasnya dikirim lewat grup WA. Jika siswa kurang mengerti dapat chat langsung ke WA pribadi atau di grup tersebut. Untuk pola belajar dan penugasan sendiri yaitu pertama saya menyuruh siswa untuk absen. Kemudian saya mengirim materi pembelajaran berupa dokumen dan rekaman suara. Setelah itu mereka membaca dan memahaminya serta bertanya apabila belum mengerti. Kemudian barulah saya memberi tugas dan waktu pengumpulan disesuaikan dengan kesulitan soal tersebut. ... ada beberapa guru yang memberikan les di rumah yang dekat dengan tempat tinggal siswa ... harus mengikuti protokol kesehatan. Biasanya ... untuk anak kelas atas seperti kelas 5 dan kelas 6. ... siswa dibagi menjadi beberapa kelompok dan masuk bergantian. Jam pelajarannya pun singkat. Mereka mencuci tangan sebelum masuk dan wajib menggunakan masker. ... tidak semua pelajaran secara luring. Jamnya pun dikurangi biasanya 30 menit atau paling lama 1 jam."

R5 Guru SD di Kabupaten Kubu Raya.

Responden lain memberikan pernyataan sebagai berikut:

Untuk daring menggunakan media WA. ... tugas segala macamnya dikirim video melalui WA. Untuk pola pembelajarannya setiap guru membuat video pembelajaran yang berisi materi. Setelah dijelaskan, penugasannya disampaikan melalui pesan tertulis di WA. Jika mengunakan media zoom, clasroom, kasian orang tuanya karena 
keterbatasan jaringan dan lain sebagainya. dengan WA bisa kirim video, pesan suara, dan tanya jawab segala macam.

R6: Guru SD di Kabupaten Mempawah.

Responden lain memberikan pernyataan sebagai berikut:

"Pakai WA. Kita kirim video, atau foto, atau rekaman, agar siswa mudah dalam menguasai pembelajaran. Tidak ada pembelajaran yang dilakukan saat pandemi," R7: Guru SD di Kabupaten Ketapang.

\section{PEMBAHASAN}

Sebanyak 7 responden telah memberikan pertnyataannya terhadap media, pola dan hambatan pembelajaran di masa pandemi COVID-19. Pernyataan tersebut lebih lanjut dibahas dan diklasifikasikan sesuai dengan jenis pembelajaran baik itu diidentifikasi sebagai pembelajaran daring atau sebagai pembelajaran luring. Pembahasan teresebut lebih lanjut dijelaskan sebagai berikut.

\section{Media yang Digunakan dalam Pembelajaran Daring}

Berdasarkan hasil wawancara terhadap responden dan temuan peneliti di lapangan, beberapa sekolah dasar di Kalimantan Barat seperti sekolah di daerah perkotaan menggunakan media daring sebagai alternatif pembelajaran selama pandemi COVID-19. Media yang digunakan dalam pembelajaran daring adalah media WhatsApp seperti yang digunakan di salah satu sekolah di Kabupaten Kubu Raya, Kabupaten Sambas, Kabupaten Ketapang dan Kabupaten Mempawah. Hal tersebut sesuai dengan pernyataan Rasmitadila, dkk. (2020) melalui ristenya menemukan bahwa WhatsApp telah digunakan dalam pembelajaran daring. Dari pernyataan guru di empat sekolah tersebut mengakui bahwa mereka menggunakan media WhatsApp. Penggunaan media tersebut sesuai dengan karakteristik daerah yang memungkinkan untuk melakukan pembelajaran daring baik itu tersedianya jaringan dan tersedianya perangkat android yang dimiliki oleh masing-masing siswa. Hal tersebut sesuai dengan instruksi pada Surat Edaran Nomor 15 BAB I Poin A nomor 5 Kementerian Pendidikan dan Kebudayaan yang menjelaskan bahwa aktivitas dan penugasan selama BDR bervariasi sesuai kondisi masing-masing sekolah.

Pemilihan penggunaan media WhatsApp sebagai media pembelajaran daring sangat membantu guru, siswa, dan orang tua dalam proses belajar mengajar. Namun, penggunaan media tersebut tidak serta merta cocok dengan karakteristik dan 
kemampuan siswa dan orang tua baik itu mengenai kesanggupan siswa dalam menerima materi yang disampaikan atau pun dari jumlah siswa atau orang tua yang memiliki android. Pada salah satu sekolah di Kabupaten Mempawah penggunan media belajar WhatsApp secara daring dilakukan secara menyeluruh di semua kompetensi dasar. Selama aktivitas di sekolah dihentikan, guru-guru di sekolah tersebut menggunakan media WhatsApp untuk semua KD di semua mata pelajaran. Di beberapa sekolah, media WhatsApp tidak sertamerta menjawab seluruh kebutuhan siswa belajar. Hal tersebut dikarenakan tidak semua materi yang disampaikan dapat dengan mudah dimengerti oleh siswa saat disampaikan melalui media WhatsApp. Seperti yang dikatakan Anggrawan (dalam Sudarsana, dkk., 2020, hal.101) yang mengatakan bahwa selama pembelajaran daring, proses pembimbingan belajar tidaklah seefektif pembelajaran tatap muka. Oleh karena itu, beberapa guru selain menggunakan media daring juga berinisiatif melaksanakan pembelajaran luring berupa les tambahan. Pembelajaran luring dengan les tersebut tentunya mengikuti instruksi pemerintah yang sesuai dengan Panduan Penyesuaian Penyelenggaraan Pembelajaran di Masa Pandemi COVID-19 yang dikeluarkan atas keputusan bersama Menteri Pendidikan dan Kebudayaan, Menteri Agama, Menteri Kesehatan, dan Menteri dalam Negeri (2020).

\section{Media yang Digunakan dalam Pembelajaran Luring}

Berdasarkan hasil wawancara terhadap responden dan temuan peneliti di lapangan, beberapa sekolah dasar di Kalimantan Barat seperti sekolah di daerah terdepan menggunakan media luring sebagai alternatif atas minimnya fasilitas pembelajaran daring. Hal tersebut sesuai dengan pernyataan yang disampaikan Herman, Kepala Dinas Pendidikan Provinsi Kalimantan Barat, mengatakan bahwa proses pembelajaran daring di masa pandemi tidak berjalan optimal karena fasilitas di daerah yang kurang (Kantor Berita Antara Kalbar, 2020).

Media yang digunakan dalam pembelajaran daring adalah media buku teks, fotokopian tugas atau materi, dan LKS yang diantar oleh guru ke rumah-rumah atau diambil oleh orang tua siswa ke sekolah. Penggunaan media ini seperti terjadi di Kabupaten Kapuas Hulu yang memang tidak memiliki kecukupan ketersediaan fasilitas daring seperti internet dan telepon seluler. Di beberapa sekolah di Kabupaten Sambas, dan Kabupaten Kayong Utara, Kabupaten Kubu Raya juga diterapkan 
pembelajaran luring dengan alasan bahwa tidak semua pelajaran dapat diterima dengan baik dengan media WhatsApp. Oleh karena itu, beberapa sekolah tidak secara konsisten melakukan pembelajaran daring. Pengunaan media belajar luring sesuai dengan Surat Edaran Nomor 15 BAB I Poin A nomor 5 Kementerian Pendidikan dan Kebudayaan BAB I Poin C nomor 2.

\section{Pola Pembelajaran Daring}

Pola pembelajaran dan penugasan siswa menggunakan media WhatsApp ratarata dilaksanakan dengan satu pola yaitu guru terlebih dahulu mengelomppokkan siswa dalam beberapa kelompok ke dalam beberapa grup WhatsApp. Dalam grup tersebutlah pembelajaran berlangsung sebagai mestinya. Guru terlebih dahulu mengabsen siswa dan selanjutnya menyampaikan materi baik itu secara tertulis, dengan bantuan video, rekaman suara, atau dengan dokumen yang telah terlebih dahulu disiapkan oleh guru sebelum materi disampaikan. Siswa membaca, mendengarkan, dan/atau menonton bahan pembelajaran yang diberikan oleh guru dalam grup WhatsApp. Beberapa siswa dibantu oleh orang tua dalam proses belajar. Beberapa di antaranya melakukannya secara mandiri. Setelah materi disampaikan, guru memberikan umpan balik, apakah siswa memahami atau tidak materi yang telah disampaikan. Komunikasi antara siswa dan guru dapat dilakukan dalam grup tersebut atau melalui pesan pribadi sehingga siswa yang belum atau sepenuhnya memahami materi yang diajarkan atau belum memahami cara mengerjakan tugas yang diberikan, dapat meminta penjelasan ulang dengan media lain atau dengan penjelasan guru secara langsung. Setelah dirasa cukup, guru selanjutnya memberikan tugas kepada siswa yang juga diberikan secara daring dalam grup WhatsApp. Saat siswa mengerjakan tugas, guru dan siswa dimungkinkan untuk melakukan komunikasi baik itu tentang kesulitan siswa dalam pengerjaan tugas. Pengumpulan tugas belajar siswa bisa dilaksanakan pada hari itu juga atau di hari berikutnya sesuai dengan tingkat kesulitan tugas yang diberikan oleh guru.

\section{Pola Pembelajaran Luring}

Berdasarkan hasil wawancara semi terstruktur terhadap reseponden dan temuan peneliti di lapangan, selain menggunakan media daring, beberapa sekolah dasar di Kalimantan Barat juga melaksanakan pembelajaran luring. Pembelajaran 
luring yang dilaksanakan sangat beragam sesuai kondisi lingkungan siswa dan sekolah.

Pertama, pembelajaran luring yang dilaksanakan dengan tugas mingguan. Pembelajaran luring dengan tugas mingguan yang dimaksud adalah pembelajaran yang diberikan kepada siswa melalui tugas-tugas yang diberikan kepada siswa lewat tugas yang telah disiapkan untuk pembelajaran selama satu minggu. Guru terlebih dahulu menyiapkan tugas untuk satu minggu. Tugas tersebut akan diserahkan kepada orang tua siswa dari rumah ke rumah oleh guru atau orang tua mengambil langsung ke sekolah. Pola pembelajaran tersebut dapat ditemui seperti di Kabupaten Kapuas Hulu. Pada sekolah tersebut, guru mengantar tugas ke rumah-rumah siswa dan selanjutnya dikerjakan oleh siswa melalui bimbingan orang tua. Alasan pengguaan pola pembelajaran ini adalah disebabkan tidak tersedianya jaringan dan telepon genggam yang memadai. Pola yang agak sedikit berbeda namun masih dalam bagian tugas mingguan adalah seperti yang dilaksanakan di Kabupaten Kayong Utara. Di sekolah tersebut, beberapa tugas belajar diambil oleh orang tua siswa ke sekolah. Namun, guru telah terlebih dahulu mengedarkan buku paket atau LKS kepada siswa dan selanjutnya penugasan bisa melalui WhatsApp.

Kedua, pembagian kelompok belajar. Pembelaran luring pola kedua adalah dilaksanakan dengan membuat kelompok belajar seperti yang dilaksanakan di beberapa sekolah di Kabupaten Sambas dan di Kabupaten Kayong Utara. Kelompok belajar dibuat oleh guru dengan cara mengelompokkan siswa yang rumahnya berdekatan. Pada setiap kelompok minimal memiliki satu perangkat android sehingga memudakan guru dalam mengirim tugas. Komunikasi antara siswa dan guru terjadi hanya pada saat pemberian dan pengumpulan tugas. Sedangkan siswa secara mandiri atau dengan bimbingan orang tua mengerjakan tugas yang telah diberikan guru. Berkumpulnya siswa disesesuaikan dengan protokol yang telah dianjurkan pemerintah.

Ketiga, pembelajaran tambahan dengan les. Pada kondisi tertentu yang memungkinkan dan sangat penting untuk dilaksanakan, guru dan siswa melakukan tatap muka dengan cara pemberian les pada kelompok-kelompok kecil. Guru dan siswa bertatap muka pada waktu dan tempat yang disepakati selama 30 menit atau paling lama 1 jam. Pelaksanaan pembelajaran tatap muka dilaksanakan dengan 
alasan, tidak semua pelajaran dapat diterima dengan baik oleh siswa yang dilaksanakan secara daring sehingga mau tidak mau, guru harus memberikan pembelajaran les. Selain itu tidak semua siswa dan orang tua siswa memiliki telepon genggam sehingga guru sulit untuk mengirim tugas. Biasanya pembelajaran dan les diperuntukkan untuk siswa yang akan memasuki ujian akhir sekolah yakni siswa kelas 6. Pelaksanaan pembelajaran les tersebut pastinya telah mengikuti instruksi pemerintah yang sesuai dengan Panduan Penyesuaian Penyelenggaraan Pembelajaran di Masa Pandemi COVID-19 yang dikeluarkan atas keputusan bersama Menteri Pendidikan dan Kebudayaan, Menteri Agama, Menteri Kesehatan, dan Menteri dalam Negeri (2020).

\section{Hambatan Pembelajaran Daring}

Beberapa hambatan dialami guru, siswa, dan orang tua siswa dalam pelaksanaan pembelajaran daring. Pertama, kurang tersedia, bahkan tidak tersedianya sarana dan prasarana pembelajaran daring. Beberapa guru dan siswa di perkampungan sulit dalam mendapatkan jaringan internet. Selain itu, beberapa siswa tidak memiliki telepon genggam android untuk menunjang pembelajaran daring. Kedua, SDM yang kurang terlatih. Beberapa guru, siswa, dan orang tua siswa mengakui kurang terlatih dalam menggunakan beberapa aplikasi pembelajaran daring sehingga pembelajaran daring hanya dilaksanakan dengan satu media saja yakni WhatsApp. Ketiga, sifat negatif guru, siswa, dan orang tua. Berdasarkan temuan di lapangan, masih terdapat guru yang merasa tidak lagi mempunyai kemampuan untuk menguasai aplikasi-aplikasi pembelajaran daring. Selain itu, siswa kurang memiliki sikap positif dalam pembelajaran secara daring sehingga tidak bersemangat dalam belajar. Hal tersebut selaras dengan pendapat Jamaludin, dkk. (2020) yang mengatakan bahwa ketidakhadiran guru dalam proses pembelajaran di rumah mengakibatkan kurangnya motivasi belajar siswa sehingga pembentukan nilai dalam proses belajar mengajar berjalan dengan lamban. Belum lagi hambatan tentang ketersedian kuota, banyaknya tugas, penguasaan teknologi, ketidakstabilan jaringan, dan lain sebagainya, begitu juga dengan beberapa orang tua yang masih menganggap pendidikan secara umum maupun pembelajaran secara daring tidak akan mampu memberikan pengetahuan kepada anaknya sehingga tidak dapat memberikan umpan positif kepada anaknya untuk belajar. 


\section{Hambatan Pembelajaran Luring}

Beberapa hambatan dialami oleh guru, siswa, dan orang tua siswa dalam pembelajaran luring. Pertama, siswa tidak dapat belajar mandiri sehingga bimbingan guru dan orang tua sangat membantu proses penerimaan materi dari proses belajar. Pada masa pandemi COVID-19, guru tidak bisa memberikan penjelasan secara langsung sedangkan orang tua tidak dapat secara penuh membimbing anaknya karena harus bekerja. Hal tersebut sesuai dengan pernyataan yang disampaikan Dewi (2020) bahwa keberhasilan pembelajaran daring dan luring dapat berhasil jika ada kerjasama antara guru, siswa, dan orang tua yang menjadi pembimbing anak saat pembelajaran di rumah dilaksanakan sehingga motivasi belajar anak menjadi meningkat.

\section{SIMPULAN}

Berdasarkan hasil pembahasan di atas, dapat diketahui bahwa terdapat dua jenis pembelajaran yang dilaksanakan di Kalimantan Barat pada masa pandemi COVID-19. Pertama adalah dengan pembelajaran daring. Guru memberikan pembelajaran secara online melalui aplikasi media sosial WhatsApp dengan mengirim teks, video, rekaman suara, power point, kepada siswa. Kedua pembelajaran luring yakni pembelajaran yang dilaksanakan tanpa melalui jaringan atau di luar jaringan. Pembelajaran tersebut bisa berupa pembelajaran dengan penugasan mingguan, pembelajaran secara berkelompok, dan pembelajaran dengan les. Hambatan yang dihadapi oleh guru, siswa, dan orang tua siswa adalah minimnya perangkat pembelajaran daring, SDM yang kurang mumpuni, dan sikap negatif baik itu dari guru, siswa, dan orang tua.

Pembelajaran daring dan luring yang dilaksanakan dengan tanpa tatap muka memerlukan sikap positif guru, siswa, dan orang tua siswa. Ketiga elemen tersebut menjadi pokok keberhasilan pembelajaran di masa pandemi COVID-19. Oleh karena itu, isu penting untuk penelitian lanjutan adalah tentang mengenai peranan orang tua dalam pembelajaran daring dan luring. Bagaimana orang tua menciptakan lingkungan belajar yang efektif dan efisien di rumah sehingga terciptanya pembelajaran yang dapat memenuhi kebutuhan peserta didik. 


\section{DAFTAR PUSTAKA}

Amrihani, dkk. (2020). Inovatif di tengah pandemi covid-19. IAIN Parepare Nusantara Press: Sulawesi Selatan.

BBC. (9 Juni 2020). COVID-19: kajian kasus di wuhan muncul sejak akhir agustus, china sebut hasil itu 'sebagai hal yang konyo', di akses pada 17 Oktober 2020, dari https://www.bbc.com/indonesia/dunia-52977852

Cahyani, A., Listiana, I.D., Larasati, S.P.D. (2020). Motivasi belajar siswa sma pada pembelajaran daring di masa pandemi covid-19. IQ (Ilmu Al-qur;an): Jurnal Pendidikan Islam, 3(1). 123-140. https://doi.org/10.37542/iq.v3i01.57

Dewi, A.F.D., (2020). Dampak covid-19 terhadap implementasi pembelajaran daring di sekolah dasar. Edukatif: Jurnal Ilmu Pendidikan, 2 (1). 55-61. https://edukatif.org/index.php/ edukatif/index

Dina, N.A.B. (2020). Respon orang tua terhadap pembelajaran daring pada masa pandemi covid-19. Thufuli: Jurnal Ilmiah Pendidikan Islam Anak Usia Dini, 2(1). $\quad$ 46-52. http://riset.unisma.ac.id/index.php/thufuli/article/download/6925/5647

Fadlilah, A.N. (2020). Strategi menghidupkan motivasi belajar anak usia dini selama pandemi covid-19 melalui publikasi. Jurnal Obsesi: Jurnal Pendidikan Anak Usia Dini, $\quad 5 \quad$ (1) 378-384. https://www.researchgate.net/publication/343966710Strategi_Menghidupkan Motivasi_Belajar_Anak_Usia_Dini_Selama_Pandemi_COVID$\underline{19 \text { melalui_Publikasi }}$

Fauzi, I., \& Khusuma, I. (2020). Teachers' elementary school in online learning of covid-19 pandemic condition. Jurnal Iqra':Kajian Ilmu Pendidikan, 5(1). 5870. https://doi.org/10.25217/ji.v5i1.914.

Gusti, Sri, dkk. (2020). Pembelajaran dari di tengah pandemi covid-19. Yayasan Kita Menulis: Medan.

Hanafi, Halid. (2018). Profesionalisme guru dalam pengelolaan kegiatan pembelajaran di sekolah. Deepublish: Yogyakarta.

Handayanim L. (2020). Peningkatan motivasi belajar ipa melalui model pembelajaran project based learning pada masa panedmi covid-19 bagi siswa smp negeri gunungsari. Jurnal Paedagogy: Jurnal Penelitian dan Pengembangan Pendidikan, 7(3). http://ojs.ikipmataram.ac.id/index.php/pedagogy/index

Herianto. (2018). Thematic analsysis sebagai metode menganalisis data untuk penelitian kualitatif. Anuva, 2(3), 317-324. http://ejournal.undip.ac.id/index.php/anuva 
Herliandry, L. D., Nurhasanah, N., Suban , M. E., \& Kuswanto, H. (2020). Pembelajaran pada masa pandemi covid-19 .JTP - Jurnal Teknologi Pendidikan, 22(1), 65-70. https://doi.org/10.21009/jtp.v22i1.15286

Jamaluddin, D.,Ratnasari, T., Gunawan, H., dan Paujiah, E. (2020). Pembelajaran daring masa pandemik covid-19 pada calon guru: hambatan, solusi, dan proyeksi. Karya Tulis Ilmiah, Lembaga Penelitian dan Pengabdian Kepada Masyarakat UIN Sunan Gunugn Djati Bandung. http://digilib.uinsgd.ac.id/30518/

Kantor Berita Antara Kalbar. (28 Mei 2020). Disdik kalbar evaluasi proses belajar daring selama covid-19, diakses pada 10 oktober 2020, dari https://kalbar.antaranews. com/berita /420664/disdik-kalbar-evaluasi-prosesbelajar-daring-selama-COVID-19.

Kompas.com. 2020. (3 Maret 2020). Fakta lengkap kasus pertama virus corona, di $\begin{array}{lllll}\text { akses } & \text { pada } & 17 & \text { Oktober } & \text { 2020, }\end{array}$ https://nasional.kompas.com/read/2020/03/03/06314981/fakta-lengkap-kasuspertama-virus-corona-di-indonesia?page $=$ all

Menteri Pendidikan dan Kebudayaan, Menteri Agama, Menteri Kesehatan, Menteri Dalam Negeri. (2020). Buku saku panduan penyesuaian penyelenggaraan pembelajaran pada tahun ajaran 2020/2021 dan tahun akademik 2020/20212 di masa pandemi corona virus disease 2019. Jakarta: Kementerian Pendidikan dan Kebudayaan.

Muhyidin, (2020). COVID-19, new normal dan perencanaan pembangunan di indonesia. The Indonesian Journal of Development Planning, 4(2) 240-252. https://journal.bappenas.go.id/index.php/jpp/article/view/118

Naziah, S.T., Maula, L.H., dan Sutrisna, A. (2020) Analisis keaktifan belajar siswa selama pembelajaran daring pada masa covid-19 di sekolah dasar. Jurnal 7(2): $109-120$. http://journal.uad.ac.id/index.php/JPSD/article/view/17327/pdf_64.

Pangondian, A.P., Santosa, P.I., Nugroho, E (2019). Faktor-faktor yang memengaruhi kesuksesan pembelajaran daring dalam revolusi industri 4.0. Sainteks: 56 - 60. https://seminar-id.com/semnas-sainteks2019.html

Pohan, Albert Efendi. (2020). Konsep pembelajaran daring berbasis pendekatan ilmiah. CV Samu Untung: Jawa Tengah.

Purwanto, A., Pramono, R., Asbari, M., Santoso, P. B., Wijayanti, L. M., Hyun, C.C., Putri, R.S., (2020). Studi ekspolratif dampak pandemi covid-19 terhadap proses pembelajaran online di sekolah dasar. EduPsyCounsJournal: 2(1).112. https://ummaspul.e-journal.id/Edupsycouns/article/view/397 
Rasmitadila, Aliyyah, R.,R., Rachamdtullah, R., Samsudin, A., Syaodih, A., Syaodih, E., Nurtanto. M., dan Tambunan, A.,R.,S., (2020). The perceptions of primary school teachers of online learning during the covid-19 pandemic period: a case study in indonesia. Journal of Ethnic Cultural Studies, 7 (2): 90-109. http://dx.doi.org/10.29333/ejecs/388

Rukin. (2019). Metodologi penelitian kualitatif. Yayasann Ahmar Cendikia Indonesia: Sulawesi Selatan.

Suara Kalbar. (15 Meret 2020). Sutarmidji: sekolah diliburkan dan masyarakat silahkan berangkat tapi jangan datang lagi ke kalbar. Diakses Pada 10 Oktober 2020, dari https://www.suarakalbar.co.id/2020/03/sutarmidji-sekolahdiliburkan-plbn-dan.html

Sudarsana, I Ketut, dkk. (2020). COVID-19 persepektif pendidikan. Yayasan Kita Menulis: Medan.

Surat Edaran Menteri Pendidikan dan Kebudayaan Republik Indonesia Nomor 15 Tahun 2020 Tentang Pedoman Penyelenggaraan Belajar dari Rumah dalam Masa Darurat Penyebaran Corona Virus Disease (COVID-19).

Suryaningsih, A. (2020). Peningkatan motivasi belajar siswa secara online pada pelajaran animas $2 \mathrm{~d}$ melalui strategi komunikasi persuasif. Ideguru: Jurnal Karya Ilmiah Guru, 5(1). dikpora.jogjaprov.go.id/index.php/jurnalideguru/article/download/143/170/

Suwartono. (2014). Dasar-dasar metodologi penelitian. CV Andi Offset: Yogyakarta.

Tarjo.(2019). Metode penelitian. Deepublish: Yogyakarta.

UNICEF, WHO, IFRC. (2020). Key messages and actions for covid-19 prevention and control in schools.

Widaningsih, Ida. (2019). Strategi dan inovasi pembelajaran bahasa indonesia di era revolusi industri 4.0. Uais Inspirasi Indonesia: Jawa Timur.

Yuliani, Meda, dkk. (2020). Pembelajaran daring untuk pendidikan: Teori dan penerapan. Yayasan Kita Menulis: Medan.

Zulkifli, dkk. (2020). Berkarya bersama di tengah covid-19. Nusantara Press: Sulawesi Selatan. 